OPEN ACCESS

Edited by:

Donagh Berry,

Teagasc Food Research

Centre, Ireland

Reviewed by:

Juan G. Maldonado-Estrada, University of Antioquia, Colombia Christian Hanzen,

University of Liège, Belgium

*Correspondence:

Thinawanga Joseph Mugwabana mugwabanatj@gmail.com

Specialty section:

This article was submitted to Animal Reproduction -

Theriogenology,

a section of the journal

Frontiers in Veterinary Science

Received: 14 April 2021

Accepted: 21 June 2021

Published: 23 July 2021

Citation:

Nengovhela NB, Mugwabana TJ, Nephawe KA and Nedambale TL (2021) Accessibility to Reproductive Technologies by Low-Income Beef Farmers in South Africa.

Front. Vet. Sci. 8:611182. doi: 10.3389/fvets.2021.611182

\section{Accessibility to Reproductive Technologies by Low-Income Beef Farmers in South Africa}

\author{
Nkhanedzeni Baldwin Nengovhela ${ }^{1}$, Thinawanga Joseph Mugwabana ${ }^{2 *}$, \\ Khathutshelo Agree Nephawe ${ }^{3}$ and Tshimangadzo Lucky Nedambale ${ }^{3}$
}

\begin{abstract}
${ }^{1}$ Department of Agriculture, Forestry, and Fisheries (South Africa), Pretoria, South Africa, ${ }^{2}$ Department of Agricultural Economics and Animal Production, School of Agricultural and Environmental Sciences, University of Limpopo, Polokwane, South Africa, ${ }^{3}$ Department of Animal Science, Tshwane University of Technology, Pretoria, South Africa
\end{abstract}

This study address historical legacy of South Africa that has dual economies resembling low and high income beef sectors. Low-income herds are farmed mainly under communal village or land reform farms. The study focused on providing assisted reproductive technologies (ARTs) to the low-income sector including finding challenges to its implementation and adoption. The study was conducted in Limpopo, Mpumalanga and KwaZulu-Natal provinces using mixed methods that looked at cows and sectors stakeholders. Data collected and evaluated on cows included breed type, frame size, body condition, age parity, and lactation status. Cows were exposed to ART through synchronisation, oestrus detection, fixed time artificial insemination and pregnancy diagnosis. Qualitative data was collected to study perception of key stakeholders on ART implementation and adoption. Chi-Square Test was computed to determine the association among cow factors. Qualitative data was collected, coded and managed into themes using Nvivo Version 11. Themes that emerged were interpreted using critical social and systems thinking. Conception rate was not independent of provinces $(P<0.05)$, cow body condition score (BCS) and body frame size. KwaZulu-Natal cows had the highest conception rate at 66\% $(P<0.05)$ than Limpopo (44\%) and Mpumalanga (60\%) provinces. Cows with a BCS higher than 3.5 had higher conception rate $(P<0.05)$ than those with BCS of $<2.5$ and 3. Interestingly, large framed cow size had higher conception rate than medium and small framed $(P<0.05)$ cows. The study achieved a $100 \%$ calf survival rate. Calving rate was influenced by body BCS, province and district $(P<0.05)$. Calving rate of 58\% in Mpumalanga and 54\% in KwaZulu-Natal was higher than that recorded in Limpopo at 36\% $(P<0.05)$. Interestingly, cows with BCS of $<2.5$ had a higher calving rate than those with a higher body condition score of 3 $(P<0.05)$. Perception study results revealed many factors that could affect the adoption and implementation of ART in the study areas. The high success rate and above average reproductive performance led to North West and KwaZulu-Natal provinces adopting ART as part of their low-income beef sector support.

Keywords: body condition score, calving rate, assisted reproductive technologies, low-income beef sector, cattle stakeholders 


\section{INTRODUCTION}

In South Africa, a dual system exists in terms of the livestock farming sector with a highly commercialised, high income and resourced sector at one end and the low-income to almost subsistence on the other end. The duality is extremely entrenched due to an extended biassed investment in agricultural infrastructure, technology, training, knowledge, and extension towards the highly commercialised sector. The low-income beef sector has a history of being neglected by value chain actors, research agencies, universities, public and non-governmental sectors even though donor organisations had always shown interest and the potential to leverage good livelihoods. The commercial livestock industry is highly sophisticated and implements appropriate technologies to ensure good value for the South African consumers but has been struggling to meet the demand of beef in the country. South Africa imported about 28.000 tonnes of beef in 2017 (1). The priority shifted to achieve the much-needed growth from the low-income sector is faced by persistent and wicked challenges requiring innovativeness to resolve. The low-income beef sector of South Africa, just like in many other Low and Middle-Income Countries (LMICs), still struggles to access inputs and services to drive productivity.

According to Statistics South Africa (2), the high-income herd holds about $60 \%$ of the national herd and the low-income herd sector commands a respectable $40 \%$. In provinces like KwaZulu-Natal, the low-income beef herd holds a majority at $70 \%$ of the provincial herd. The common breeds of cattle that are found in the low-income beef sector are the Nguni, Bonsmara, Brahman, and other non-descript breeds. The low-income herd has little contribution to the formal national beef industry's income of R128 billion (2). Cattle productivity in communal lands is generally poor in terms of calving percentages $(<40 \%)$, high calf mortality rates $(>35 \%)$, low weaning weights $(<180 \mathrm{~kg}$ at day 205), low post-weaning growth, and high mortality rate (3$5)$. These are some of the old problems besetting the sector and complemented by other socio-economic challenges (6). Under the low-income beef production systems, cows rarely conceive within a year of calving, calving intervals of 2-3 years are common $(4,5,7)$. According to Stroebel et al. (8), the long calving interval could be attributed to the fact that few farmers wean calves and the majorities allow calves to run with the dams until natural separation occurs. The list of contributors to constraint productivity is vast and had been well-documented.

South Africa has over 483.270 farmers with beef herds of $<10$ animals, about 118.000 that own more than 10 animals, and only about 14.000 that owns more than 100 animals (2). Herd size was considered a major constraint to increasing cattle productivity and efficiency within the low-income herd in several studies (8-10). Attempts to address stocking rates, reproductive rates, growth rates, and access to markets are frustrated by the scale of production, and there were several attempts to address it through organisational rearrangements in most cases with little success. So, initiatives that aggregate these herds are a must to form bases for effective support and access to inputs and services.

Another constraint that affects the reproductive performance of this herd is the herd inventory that has females making up the largest proportion of the herd $(8,10)$. Farmers with small herds hope to grow their herds by keeping all females and use males for sale or as castrates for other uses. This leads to many households with no breeding bulls at the herd level or a very high bull to cows' ratio at the village level. The breeding is therefore left to chance at the communal grazing areas leading to inbreeding and reduced fitness $(5,6,11)$. South Africa has a long history of performance testing and genetic evaluation, but none of these pricey sires can find their way into these herds other than through government or donor support, so superior animals are hardly used in the low-income herds.

Livestock farmers in the low-income sector in South Africa rely on extension services offered by the government, which is considered inadequate $(5,12)$. The challenges in the low-income beef sector are enormous, thus requiring some innovativeness. Any intervention strategies and actions will need to be built on a clear understanding of these challenges; otherwise, the status core will remain.

The commercial beef sector had relied on the use of technologies to support their productivity. Smallholder and low-income beef farmers can adopt and implement the same technologies to drive productivity in the sector. According to Ndove et al. (13) and Muzari et al. (14), key drivers of technology implementation and usage by rural farmers are assets, vulnerability, and institutions. The South African government, through its Technology Innovation Agency funding incubator, the Agricultural Research Council (ARC), three Provincial Departments of Agriculture, and two Universities implemented the Livestock Development Programme in 2012. The programme introduced assisted reproductive technologies (ARTs) in smallholder cattle farmers in Limpopo, Mpumalanga, and KwaZulu-Natal provinces. The programme was designed as an integrated initiative to address the problem of bull shortages, access to improved genetics, to improve reproductive performance of cows and barriers of adoption in the sector. ARTs seldom exist in communal and emerging farming systems in South Africa, not only because of the cost factor but also because the free support systems are not designed to implement them at the sector level. The project was to present the observable feasibility of implementing ARTs and improvement of reproductive performance under the low-income sector. The aim of this study was to evaluate the effect of the implementation of ARTs to improve production under the low-income beef sector to develop policy directives for successful implementation of the project among low-income farmers.

\section{MATERIALS AND METHODS}

\section{Study Area}

The study used a multidisciplinary approach and was conducted in three provinces of South Africa, namely: Limpopo (LP), Mpumalanga (MP), and KwaZulu-Natal (KZN) provinces. The selected districts for the study were; Vhembe, Capricorn, Mopani and Waterberg (LP), and Gert Sibande and Ehlanzeni (MP), Zululand and Harry Gwala (KZN). A large part of these provinces is rural, with a large number of organised low-income beef cattle farmers. Limpopo province covers an area of $125.755 \mathrm{~km}^{2}$ and 


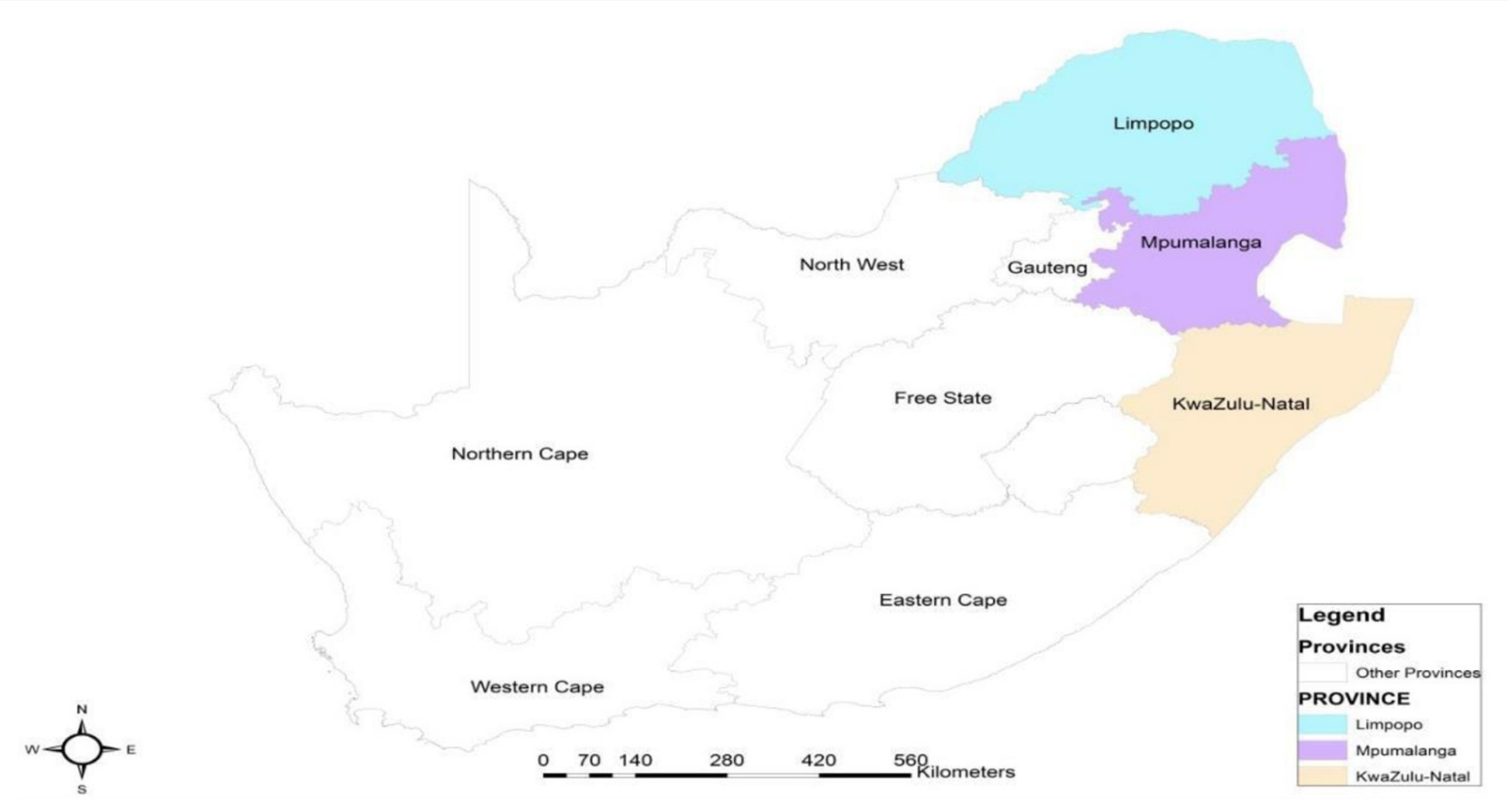

FIGURE 1 | Map of the Republic of South Africa showing the study area.

is located in the northern part of the country. Rainfall in the province ranges from 346 to $1,560 \mathrm{~mm}$ per annum. Its average summer and winter temperature are 27 and $15^{\circ} \mathrm{C}$, respectively (15-17). Mpumalanga province covers a total area of $76.495 \mathrm{~km}^{2}$. The province is located in the north-eastern part of the country. Rainfall averages between 600 and $1,600 \mathrm{~mm}$ per annum with daily average summer and winter temperatures of 24 and $14.8^{\circ} \mathrm{C}$, respectively $(15,18)$. KwaZulu-Natal is a province of $94.361 \mathrm{~km}^{2}$ in size. The province receives an average of $1,000 \mathrm{~mm}$ rainfall per annum. Summer temperatures average $28^{\circ} \mathrm{C}$, and winter temperatures seldom fall below $17^{\circ} \mathrm{C}$ in mid-winter $(15,19)$. Figure 1 shows a map of the Republic of South Africa showing the study area.

\section{Identification of Key Stakeholder}

A stakeholder analysis tool was used to determine stakeholder with power and interest in the implementation of the ART project (20). Key stakeholders who were identified and participated in the project were; Technology Innovation Agency (TIA), ARC, Provincial Departments of Agriculture, cattle farmers, and universities. TIA provided funding for the project; ARC was the main drivers of the project; Provincial Departments of Agriculture co-ordinated the project at a provincial level; cattle farmers willingly provided their cows to be used as experimental units; universities helped in providing study opportunities and funding for studies.

\section{Selection of Cows Used}

Cows used in the trial were selected at random. Selected cows were then screened for age (4 years and older), non-pregnant, normal reproduction cycle, parity (should have given birth before regardless of the number), body condition score $(\leq 2.5$ to $\geq 3.5$ ) and disease-free, especially contagious abortion. Cows were then grouped according to province, district, breed type, parity, age, frame size, lactation status, and body condition score ranging from 1 to 5 (21). The different breeds were identified by their phenotypic traits of resemblance to either the Nguni, Bonsmara, or Brahman type.

\section{Oestrous Synchronisation and Artificial Insemination}

Experimental cows were synchronised using the ovsynch protocol that allows for fixed-time artificial insemination (FTAI) following synchronisation. On day 0 , cows were given a dose of vitamin (Atlantic Gold ${ }^{\circledR}$ ) to boost their immunity and body condition and were inserted in their vagina with controlled internal drug release $\left(\mathrm{CIDR}^{\circledR}\right.$, New Zealand) device containing $1.9 \mathrm{~g}$ progesterone. On day $8, \mathrm{CIDR}^{\circledR}$ was removed, and cows were immediately inspected for pregnancy using both rectal palpation and ultrasound scanner. Those cows that were not pregnant were then immediately injected i.m with $2.5 \mathrm{ml}$ of Estrumate (PGF2 $\alpha)$ to stimulate ovulation. On day 9, cows were injected i.m with $1 \mathrm{ml}$ of estradiol benzoate (EB) and then mounted with a heat mount detector (Kamar ${ }^{\circledR}$, USA) on their tail head. The device change colour to red when a cow was mounted (indicating a positive response to the protocol).

Artificial insemination (AI) was performed $12 \mathrm{~h}$ after EB injection. Frozen-thawed semen of registered Nguni bulls of superior fertility was used. Semen quality was evaluated before 
TABLE 1 | Effect of province and districts on synchronisation response and conception rate of cows under communal and emerging farming systems.

\begin{tabular}{|c|c|c|c|c|c|c|c|c|}
\hline Variables & $\begin{array}{c}\text { Number } \\
\text { synchronised }\end{array}$ & $\begin{array}{l}\text { Synchronisation } \\
\text { response rate }\end{array}$ & $\begin{array}{l}\text { Number of cows } \\
\text { inseminated }\end{array}$ & $\begin{array}{l}\text { Number } \\
\text { conceived }\end{array}$ & $\begin{array}{l}\text { Conception } \\
\text { rate }\end{array}$ & $\begin{array}{l}\text { Contribution towards } \\
\text { conception }\end{array}$ & $\begin{array}{l}\text { Chi-square } \\
\text { value }\end{array}$ & $P$-value \\
\hline \multicolumn{9}{|l|}{ Province } \\
\hline Limpopo & 108 & 100 & 108 & 47 & 43.52 & 17.22 & 10.6047 & 0.0050 * \\
\hline Mpumalanga & 91 & 100 & 91 & 55 & 60.44 & 20.15 & & \\
\hline $\mathrm{KZN}$ & 83 & 100 & 74 & 49 & 66.22 & 17.94 & & \\
\hline Total & 282 & 100 & 273 & 151 & 55.31 & 55.31 & & \\
\hline \multicolumn{9}{|l|}{ Districts } \\
\hline Vhembe & 48 & 100 & 48 & 25 & 52.08 & 9.16 & 3.5210 & 0.3180 \\
\hline Capricorn & 37 & 100 & 37 & 13 & 35.14 & 4.76 & & \\
\hline Mopani & 13 & 100 & 13 & 04 & 30.77 & 1.47 & & \\
\hline Waterberg & 10 & 100 & 10 & 05 & 50.00 & 1.83 & & \\
\hline Gert Sibande & 69 & 100 & 69 & 43 & 62.32 & 15.75 & & \\
\hline Ehlanzeni & 22 & 100 & 22 & 12 & 54.55 & 4.39 & & \\
\hline Zululand & 55 & 100 & 46 & 30 & 65.22 & 10.99 & & \\
\hline Harry Gwala & 28 & 100 & 28 & 19 & 67.86 & 6.96 & & \\
\hline Total & 282 & 100 & 273 & 151 & 55.31 & 55.31 & & \\
\hline
\end{tabular}

${ }^{*}$ Significant relationship (not independent) $(P<0.05)$.

insemination using Computer Aided Sperm Analysis (CASA) before insemination, and semen of high sperm motility $(\geq 75)$ were used. Cows were inseminated twice at $12 \mathrm{~h}$ interval on day 10 and again on day 11 (late afternoon and early morning). Pregnancy diagnosis was performed 90 days later through both the use of a scanner and hand palpation.

\section{Statistical Analysis of Collected Data}

The data collected were on province, district, breed type, parity, age, body condition score, frame size, and lactation status. The data collected was captured in Microsoft Excel 2013 and FREQ procedure of Statistical Analysis System (22) was used for descriptive statistics according to the collected data. ChiSquare Test of Independence were computed between dependent and independent variables. Qualitative data was collected using a semi-structured questionnaire that was developed and administered to identified stakeholder to determine their perception of the implementation and adoption of the project under the low-income beef sector. Qualitative data collected was analysed using Nvivo version 10 computer software package developed by QSR International Ltd. Whole sentences and paragraphs were coded, and emerging themes captured, analysed, and interpreted on how they could affect the implementation and adoption of ART under low-income beef sector using critical social theory and systems thinking (23).

\section{RESULTS}

\section{Oestrous Synchronisation Response and Conception Rate}

The study recorded an oestrous synchronisation response and conception rate of 100 and 55\%, respectively (Table 1). The computed Chi-Square Test of Independence showed that the conception rate was not independent of the province. Conception rates in MP (60\%) and KZN (66\%) were significantly higher $(P$ $<0.05)$ than that obtained in LP. No significant difference $(P$ $>0.05$ ) was found between MP and KZN, and within districts of different provinces. However, Gert Sibande (62\%) of the MP recorded the highest conception rate, whereas the least conception rate was recorded in the Mopani (31\%) district of the LP. Chi-Square Test of Independence showed that breed type, and body frame size has no association with conception rate (Table 2). There was a small fraction of Afrikaner, Drakensberg, Simmentaler, and non-descript breeds that were classed as other, and were neglected in further discussions because of the small group's size. Brahman (63\%) breed-type cows recorded the highest conception rate, whereas the least conception rate was recorded in Nguni (54\%). Conception was independent of parity and age of the cows under communal and emerging farming systems (Table 3$)$. Cows in fifth $+(71 \%)$ parity had the highest conception rate, whereas the least conception rate was recorded in second $(51 \%)$ parity cows. Cows aged $8+(83 \%)$ had the highest conception rate, whereas the least conception rate were recorded in cows aged 5 and 6 (both at 49\%) years. The conception rate was not independent $(P<0.05)$ of body condition score (Table 4). Cows of body condition score of $\leq 2.5$ and $\geq 3.5$ had significantly higher $(P<0.05)$ conception rate than cows of body condition score of 3 . There was no significant difference $(P>0.05)$ in the conception rate of cows of body condition score of $\leq 2.5$ and $\geq 3.5$. The lactation status of a cow was independent of conception $(P>0.05)$.

\section{Calving and Survival Rate Following Timed Artificial Insemination}

A calving and survival rate of 48 and $100 \%$, respectively, was recorded in the current study (Table 5). Calving rate was not independent of province and district. The calving rate in MP (58\%) and KZN (54\%) was significantly higher 
TABLE 2 | Effect of breed and body frame size on synchronisation response and conception rate of cows under communal and emerging farming systems.

\begin{tabular}{|c|c|c|c|c|c|c|c|c|}
\hline Variables & $\begin{array}{c}\text { Number } \\
\text { synchronised }\end{array}$ & $\begin{array}{l}\text { Synchronisation } \\
\text { response rate }\end{array}$ & $\begin{array}{l}\text { Number of cows } \\
\text { inseminated }\end{array}$ & $\begin{array}{l}\text { Number } \\
\text { conceived }\end{array}$ & $\begin{array}{l}\text { Conception } \\
\text { rate }\end{array}$ & $\begin{array}{l}\text { Contribution towards } \\
\text { conception }\end{array}$ & $\begin{array}{l}\text { Chi-square } \\
\text { value }\end{array}$ & $P$-value \\
\hline \multicolumn{9}{|l|}{ Breed type } \\
\hline Brahman & 30 & 100 & 30 & 19 & 63.33 & 6.96 & & \\
\hline Nguni & 184 & 100 & 177 & 95 & 53.67 & 34.80 & & \\
\hline Other ${ }^{\ddagger}$ & 11 & 100 & 10 & 09 & 90.00 & 3.29 & & \\
\hline \multicolumn{9}{|c|}{ Body frame size } \\
\hline Small & 53 & 100 & 53 & 26 & 49.06 & 9.52 & 5.9008 & 0.0523 \\
\hline Medium & 212 & 100 & 203 & 111 & 54.68 & 40.66 & & \\
\hline Large & 17 & 100 & 17 & 14 & 82.35 & 5.13 & & \\
\hline Total & 282 & 100 & 273 & 151 & 55.31 & 55.31 & & \\
\hline
\end{tabular}

${ }^{\ddagger}$ Other $=($ Afrikaner $=2$, Drakensberg $=3$, Simmentaler $=1$ and non-descript $=4)$.

TABLE 3 | Effect of parity and age on synchronisation response and conception rate of cows under communal and emerging farming systems.

\begin{tabular}{|c|c|c|c|c|c|c|c|c|}
\hline Variables & $\begin{array}{c}\text { Number } \\
\text { synchronised }\end{array}$ & $\begin{array}{l}\text { Synchronisation } \\
\text { response rate }\end{array}$ & $\begin{array}{l}\text { Number of cows } \\
\text { inseminated }\end{array}$ & $\begin{array}{l}\text { Number } \\
\text { conceived }\end{array}$ & $\begin{array}{l}\text { Conception } \\
\text { rate }\end{array}$ & $\begin{array}{l}\text { Contribution towards } \\
\text { conception }\end{array}$ & $\begin{array}{l}\text { Chi-square } \\
\text { value }\end{array}$ & $P$-value \\
\hline \multicolumn{9}{|l|}{ Parity } \\
\hline Second & 79 & 100 & 74 & 38 & 51.35 & 13.92 & & \\
\hline Third & 48 & 100 & 47 & 29 & 61.70 & 10.62 & & \\
\hline Unknown & 25 & 100 & 25 & 09 & 36.00 & 3.29 & & \\
\hline Total & 282 & 100 & 273 & 151 & 55.31 & 55.31 & & \\
\hline \multicolumn{9}{|c|}{ Age (years) } \\
\hline 4 & 107 & 100 & 104 & 60 & 57.96 & 21.98 & 9.6947 & 0.0844 \\
\hline 5 & 51 & 100 & 49 & 24 & 48.97 & 8.79 & & \\
\hline Total & 282 & 100 & 273 & 151 & 55.31 & 55.31 & & \\
\hline
\end{tabular}

than that obtained in LP $(36 \%)$. There was no significant difference $(P>0.05)$ between the calving rate in MP and KZN provinces. In LP province, the Vhembe (44\%) district had a significantly higher $(P<0.05)$ calving rate than that recorded in Capricorn (32\%), Mopani (23\%), and the Waterberg (30\%) districts. In Mpumalanga province, Gert Sibande (61\%) had a significantly higher calving rate than the Ehlanzeni (50\%) district. In KZN province, there was no significant difference between Zululand (50\%) and Harry Gwala (61\%) district. There was no significant difference $(P>0.05)$ between the Ehlanzeni district of Mpumalanga, Zululand, and Harry Gwala of KZN and the Vhembe district of LP.

Breed type and body frame size had no association with calving and survival rate (Table 6). However, the Brahman (53\%) breed type had a higher calving rate than Bonsmara (46\%) and Nguni (48\%) breed type cows. Again, there was a small group classed as other that were neglected in the further discussion because of the group's small size.

Cows with a large body frame (65\%) had the highest calving rate compared to small (43\%) and medium (48\%) framed cows. Parity and age had to association with calving and survival rate (Table 7). However, cows in the fifth $+(71 \%)$ parity had the highest calving rate than the first $(46 \%)$ parity cow, which also happens to be the least calving recorded in the study. Additionally, cows aged $8+(67 \%)$ had the highest calving, whereas the least calving was recorded in cows aged $6(45 \%)$ years. Chi-Test of Independence showed that body condition score was not independent of calving ( $P<0.05$; Table 8). Cows of body condition score of $\leq 2.5(60 \%)$ had a significantly higher $(P<0.05)$ calving rate than those with body condition score of 3 (43\%). However, there was no significant difference $(P>0.05)$ between cows of body condition scores of 3 and $\geq 3.5$. Lactation 
TABLE 4 | Effect of body condition score and lactation status on synchronisation response and conception rate of cows under communal and emerging farming systems.

\begin{tabular}{|c|c|c|c|c|c|c|c|c|}
\hline Variables & $\begin{array}{c}\text { Number } \\
\text { synchronised }\end{array}$ & $\begin{array}{l}\text { Synchronisation } \\
\text { response rate }\end{array}$ & $\begin{array}{l}\text { Number of cows } \\
\text { inseminated }\end{array}$ & $\begin{array}{l}\text { Number } \\
\text { conceived }\end{array}$ & $\begin{array}{l}\text { Conception } \\
\text { rate }\end{array}$ & $\begin{array}{l}\text { Contribution towards } \\
\text { conception }\end{array}$ & $\begin{array}{l}\text { Chi-square } \\
\text { value }\end{array}$ & $P$-value \\
\hline \multicolumn{9}{|c|}{ Body condition score } \\
\hline 3 & 180 & 100 & 176 & 85 & 48.30 & 31.14 & & \\
\hline$\geq 3.5$ & 34 & 100 & 32 & 23 & 71.88 & 8.42 & & \\
\hline Total & 282 & 100 & 273 & 151 & 55.31 & 55.31 & & \\
\hline Dry & 179 & 100 & 172 & 98 & 56.98 & 35.90 & 0.8145 & 0.3668 \\
\hline Lactating & 103 & 100 & 101 & 53 & 52.48 & 19.41 & & \\
\hline Total & 53 & 100 & 273 & 151 & 55.31 & 55.31 & & \\
\hline
\end{tabular}

*Significant relationship (not independent) $(P<0.05)$.

TABLE 5 | Effect of province and districts on calving and survival rate of cows under communal and emerging farming systems.

\begin{tabular}{|c|c|c|c|c|c|c|c|}
\hline Variables & $\begin{array}{l}\text { Number of cows } \\
\text { inseminated }\end{array}$ & $\begin{array}{c}\text { Number of cows } \\
\text { calved }\end{array}$ & Calving rate & Survival rate & $\begin{array}{c}\text { Contribution towards } \\
\text { calving }\end{array}$ & $\begin{array}{l}\text { Chi-square } \\
\text { value }\end{array}$ & $P$-value \\
\hline \multicolumn{8}{|l|}{ Province } \\
\hline Mpumalanga & 91 & 53 & 58.24 & 100 & 10.41 & & \\
\hline KZN & 74 & 40 & 54.05 & 100 & 14.65 & & \\
\hline Vhembe & 48 & 21 & 43.73 & 100 & 7.69 & 15.3765 & $0.0001^{*}$ \\
\hline Capricorn & 37 & 12 & 32.43 & 100 & 4.39 & & \\
\hline Mopani & 13 & 03 & 23.08 & 100 & 1.10 & & \\
\hline Waterberg & 10 & 03 & 30.00 & 100 & 1.10 & & \\
\hline Gert Sibande & 69 & 42 & 60.87 & 100 & 15.38 & & \\
\hline
\end{tabular}

${ }^{*}$ Significant relationship (not independent) $(P<0.05)$.

TABLE 6 | Effect of breed and body frame size on calving and survival rate of cows under communal and emerging farming systems.

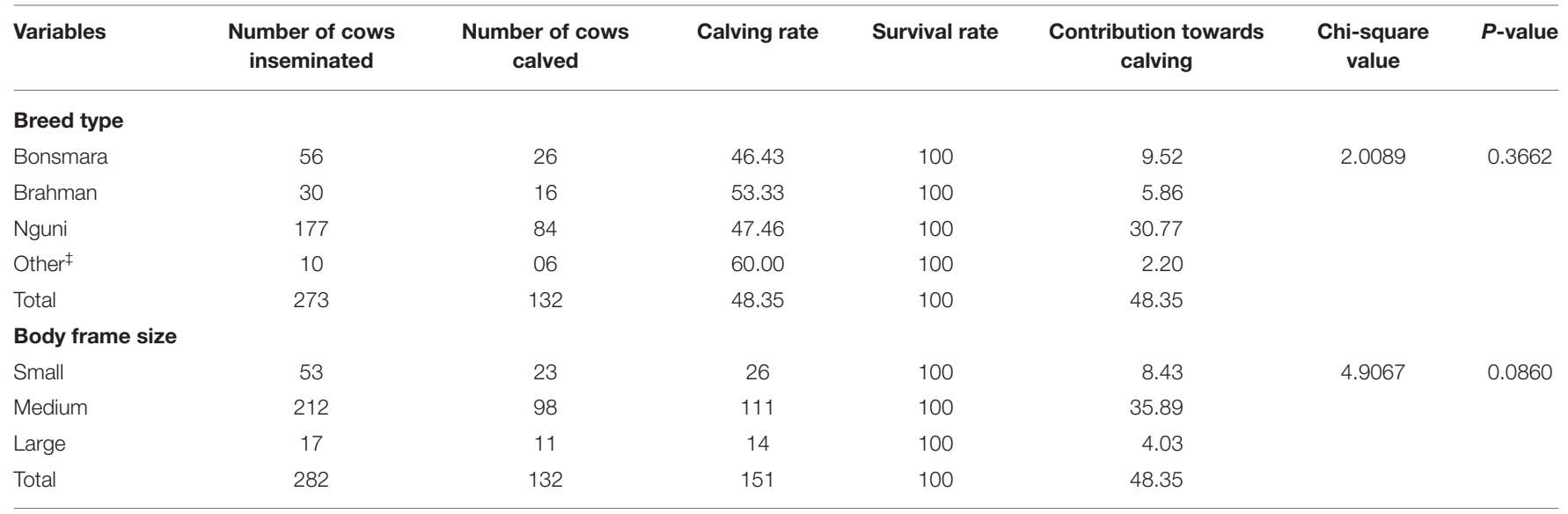

${ }^{\ddagger}$ Other $=($ Afrikaner $=2$, Drakensberg $=3$, Simmentaler $=1$ and non-descript $=4)$. 
TABLE 7 | Effect of parity and age on calving and survival rate of cows under communal and emerging farming systems.

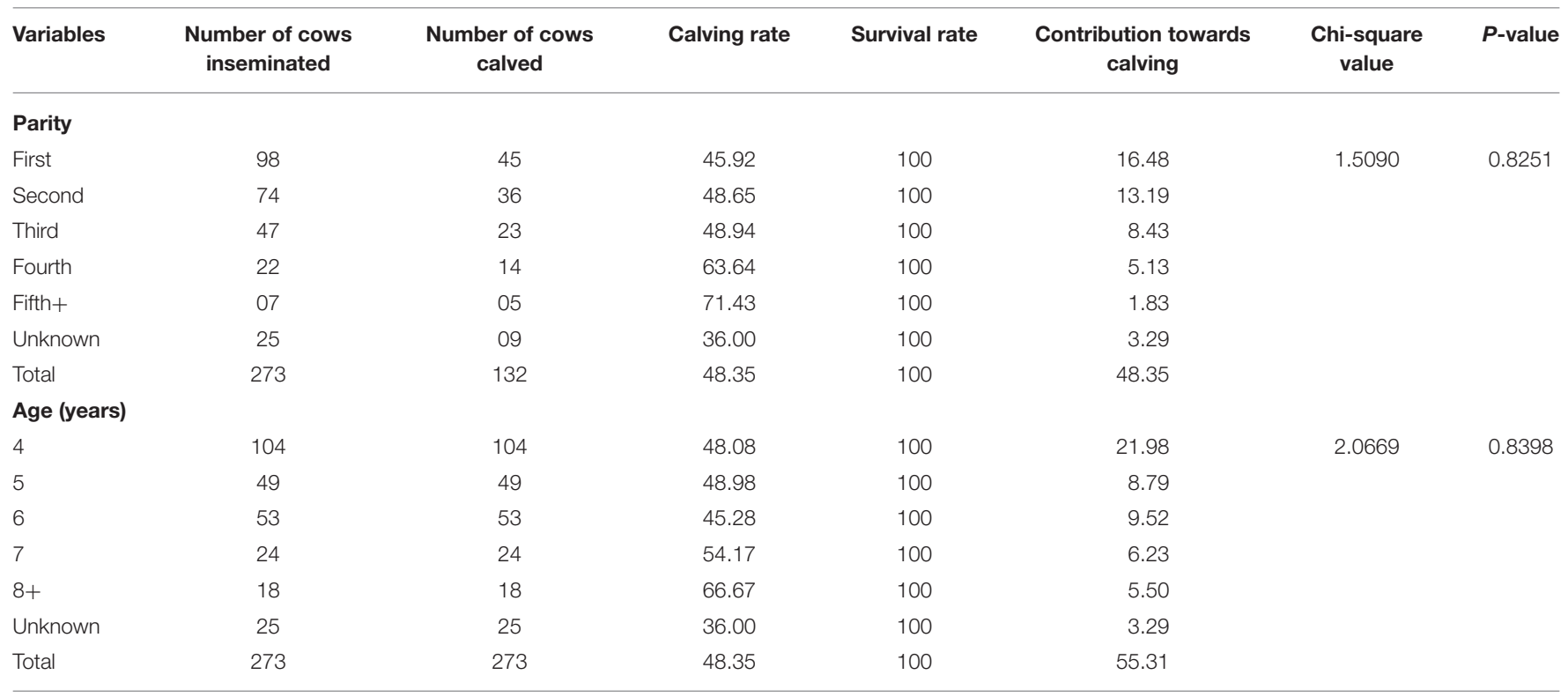

TABLE 8 | Effect of body condition score and lactation status on calving and survival rate of cows under communal and emerging farming systems.

\begin{tabular}{|c|c|c|c|c|c|c|c|}
\hline Variables & $\begin{array}{l}\text { Number of cows } \\
\text { inseminated }\end{array}$ & $\begin{array}{l}\text { Number of cows } \\
\text { calved }\end{array}$ & Calving rate & Survival rate & $\begin{array}{c}\text { Contribution towards } \\
\text { calving }\end{array}$ & $\begin{array}{l}\text { Chi-square } \\
\text { value }\end{array}$ & $P$-value \\
\hline \multicolumn{8}{|c|}{ Body condition score } \\
\hline 3 & 176 & 76 & 43.18 & 100 & 27.84 & & \\
\hline$\geq 3.5$ & 32 & 17 & 53.12 & 100 & 6.23 & & \\
\hline Dry & 172 & 172 & 98 & 100 & 30.77 & 1.4151 & 0.2342 \\
\hline Lactating & 101 & 101 & 53 & 100 & 17.58 & & \\
\hline Total & 273 & 273 & 151 & 100 & 48.35 & & \\
\hline
\end{tabular}

${ }^{*}$ Significant relationship (not independent) $(P<0.05)$.

status of a cow had no significant relationship $(P>0.05)$ with calving rate under the low-income beef sector.

\section{Stakeholder Perception Analysis}

Cattle farmers and Provincial Departments of Agriculture (PDAs) were key stakeholders in the low-income beef sector in South Africa. A total of 28 cattle stakeholders were identified for the interview. A multitude of challenges emerged that compromise the implementation and adoption of reproductive technologies under the low-income beef sector (Table 9). Challenges were grouped into three categories, namely; human interference, lack of resources and those emanating from natural causes.

The two most common constraints relating to human interference that was perceived to affect the implementation and adoption of reproductive technologies under the low-income beef sector as given by respondents in all provinces in order of rankings were: stock theft and expansion of dwelling areas.
Two prominent challenges emanating from lack of resources were that potentially can reduce the accessibility of reproduction technologies in the low-income beef sector in order of ranking were: inadequate infrastructure and lack of access to the market. Perceived main challenges of natural causes in the three provinces that potentially reduces access to reproductive technologies were: drought and dry season, and diseases.

\section{DISCUSSION}

\section{Cow Performance}

\section{Oestrous Synchronisation Response}

Results recorded in the current study are comparable with those reported by Martinez et al. (24) in beef cattle when EB and progesterone were used, and those by Maqhashu (25) who reported 99 and $100 \%$ synchronisation response rate in cows under low-income beef sector in LP and KZN, respectively. Rahman et al. (26) also reported a 100\% synchronisation 
TABLE 9 | Challenges to the accessibility of reproductive technologies by low-income beef farmers in South Africa.

\begin{tabular}{|c|c|c|}
\hline Human interference & Lack of resources & Natural causes \\
\hline $\begin{array}{l}\text { Expansion of dwelling } \\
\text { areas }\end{array}$ & $\begin{array}{l}\text { Inability to supplement } \\
\text { animals }\end{array}$ & $\begin{array}{l}\text { Sores and injuries due } \\
\text { to horns and thorns }\end{array}$ \\
\hline Dispute by stakeholders & $\begin{array}{l}\text { Inadequate } \\
\text { infrastructure }\end{array}$ & $\begin{array}{l}\text { Drought and dry } \\
\text { season }\end{array}$ \\
\hline Stock theft & Lack of medication & Lightning \\
\hline $\begin{array}{l}\text { Delayed and lack of } \\
\text { government serves }\end{array}$ & $\begin{array}{l}\text { Lack of access to the } \\
\text { market }\end{array}$ & $\begin{array}{l}\text { High pre-weaning } \\
\text { mortality }\end{array}$ \\
\hline Inbreeding & Shortage of grazing land & Predators \\
\hline Poor cattle management & Shortage of bulls & Global warning \\
\hline $\begin{array}{l}\text { Lack of cattle farming } \\
\text { strategy }\end{array}$ & $\begin{array}{l}\text { Lack of good breeding } \\
\text { materials }\end{array}$ & $\begin{array}{l}\text { High incidence of } \\
\text { abortion }\end{array}$ \\
\hline Fire outbreak & $\begin{array}{l}\text { Insufficient government } \\
\text { services }\end{array}$ & \\
\hline Labour regulations & & \\
\hline
\end{tabular}

response rate in supplemented crossbred cows in Bangladesh. However, the results differ from those reported by other authors. Raphalalani (27) reported an overall synchronisation response rate of $75 \%$ in LP under the emerging farming sector. Cabara and Velicevici (28) reported a synchronisation response rate of 63 percent in smallholder dairy cows in Romania. According to Martinez et al. (24), the use of EB in place of GonadotropinReleasing Hormone $(\mathrm{GnRH})$ improves the expression of oestrous in beef cattle. Tropical breeds have a particular temperament that results in a "silent" or "missed" heat (29). Furthermore, tropical breeds have smaller corpus luteum that affect serum progesterone levels and subsequently lower response to oestrogen and oestrus behaviour $(29,30)$. Bó et al. (29) and Alvarez et al. (30) suggested that exposure to stressors (environmental or animal derived) could decrease oestrus expression and normal ovulation. Alnimer et al. (31) and Hansen (32) described heat stress among the factors affecting the reproduction and oestrous manifestation in cows. Stress emanating from excessive heat can reduce follicular development, which in turn reduces oocyte growth, lowering the expression of oestrous behaviour and increasing undetected oestrous (28). The anticipation from this study was that it would be difficult to synchronise beef cattle under low-income sector since the project was conducted during the summer months (October to March) when the environmental temperature averages $30^{\circ} \mathrm{C}$.

The heat mount detectors assisted in the detection of cows on heat. The detector requires a cow to stand immobile and be mounted by another animal in order for the patch to turn red. Mounting behaviour can affect the synchronisation response rate. The number of mounts increased as the number of cows in oestrous increased (33). Discrepancies in the use of heat mount detectors cannot be ruled out. For example, an animal may move away after another animal attempt to mount it under veld farming conditions. An animal could also use a tree branch for scratching itself, causing the detector to give a false positive reading.

\section{Conception Rate of Synchronised Cows}

Fertilisation failure is the most important factor reducing the accomplishment of reproductive programmes in dairy and beef cattle. The current study observed an overall conception rate of $55 \%$. This result falls within the suggested conception rate of between 25 and $67 \%$ as reported by Baruselli et al. (34), conception rates of between 50 and $90 \%$ suggested by Borges et al. (35) and conception rates of between 40 and $60 \%$ suggested by Woldu et al. (36). The results show an improvement when compared with previous documented indigenous low-income beef cattle conception rates such as $27.06 \%$ in Ethiopia (37), 41\% in South Africa (27), 47.5\% in Ethiopia (38), 48.3\% in Ethiopia (36), and $47 \%$ in South Africa (25). The results are lower than those stated by other researchers such as Ali et al. (38) who reported a conception rate of $62.5 \%$ in Ethiopia, Garcia et al. (39) who reported a conception rate of $61.4 \%$ in the Amazon basin of Peru, and Baruselli et al. (34) who reported a conception rate of $85 \%$ in Brazil.

The differences in conception might be due to different hormones and management systems. Studies by Desalegn (37), Mukasa-Mugerwa et al. (40), and Woldu et al. (36) relied on heat detection before insemination based on the "ampm guideline." In their studies, cows observed to be on heat in the morning were inseminated that very afternoon, and those identified in the afternoon were inseminated the following morning. The peak time for an animal to display oestrus is usually overnight, and its duration is short (34, $41,42)$, it is possible to inseminate the animal late due to poor oestrus detection processes by the farmers. Furthermore, under extensive communal and emerging beef cattle farming, animals graze extensively in camps at walking distance from the homestead, which might also compromise the oestrous detection process. However, Chebel et al. (43) in California (USA) found that the type of insemination protocol, timed AI or AI upon oestrus detection, results in similar conception rates. Furthermore, studies by Baruselli et al. (34) and Raphalalani (27) used the ovsynch protocol similar to the one used in the current study with varying results, proving that conception is a multifaceted product. Stress emanating from excessive heat is a major cause of low cow fertility and pregnancy rate following AI (29). Infertility and subfertility of cows under communal and emerging systems may also have reduced the conception rate.

In the present study, the province had a significant effect on conception. The conception was highest in KZN (66\%) rather than in MP (60\%) and LP (44\%). The vegetation and available grazing are dependent on rainfall, and KZN is South Africa's most watered province with an average of over $1,000 \mathrm{~mm}$ of rainfall per annum $(15,19)$. An abundance of vegetation in an area is manifested through good body conditions of the animals, which in turn affects the conception rate $(26,34,41)$. Cows with a body condition score of $\geq 3.5(72 \%)$ had the highest conception rate compared to those with a score of $3(48 \%)$ and $\leq 2.5(66 \%)$. Bó et al. (44) and Woldu et al. (36) observed an increase in conception rate with increased body condition score when working with village cows in Brazil and Ethiopia, respectively. The nutritional status of the animal 
affects ovarian function, which in turn affects their reproductive performance (45).

Cows that were not suckling a calf had a higher conception rate (57\%) than those that were lactating (53\%), although the difference was not significant $(P>0.05)$. Beef cattle are characterised by prolonged post-partum anoestrous, which will affect their conception rate (46). Poor management such as lack of weaning can add to this problem. When weaning is delayed, cows take much longer to restore their body condition, affecting their conception rate.

There was no difference in conception rate between animals of different sizes. However, under natural farming systems where feed availability is seasonal, farming with small to medium framed animals such as the Nguni can be beneficial. The Nguni has a low maintenance feed requirement and is adapted to local conditions (47). When compared with an equal amount of data, the Nguni has demonstrated that it can perform better than the Bonsmara and Brahman (27).

\section{Calving and Survival Rate}

Calving rate has been used to measure reproductive performance under the low-income beef sector in South Africa. The current study recorded an overall calving rate of $48 \%$. A conception rate of $55 \%$ was recorded, thus giving a pregnancy loss of $7 \%$. The calving results are an improvement on the $40 \%$ reported under natural mating in the low-income beef sector $(8,48)$. Pursley et al. (49) recorded an overall calving rate of $29 \%$ with a pregnancy loss of $20 \%$ in dairy herds in the US. Mokantla et al. (3) recorded a calving rate of $38 \%$ under natural service in village farming areas of South Africa with a pregnancy loss of $12 \%$. The current pregnancy loss is rather lower than that reported by Pursley et al. (49) and Mokantla et al. (3).

The current study recorded a $100 \%$ survival rate. However, since beef cattle under the low-income sector graze on rangelands that are a distance at times of about $12 \mathrm{~km}$ from homesteads (45), farmers can have missed out on some of the calves that might have died immediately after calving. Cattle are hardly kraaled in many villages unless they are to be worked on. Leaving cattle out in bushy dense veld can potentially expose the newly born and the young to predators. Some villages are located close to wildlife reserves (50), and the potential for wildlife such as hyenas, wild dogs, and leopards to scavenge on the young and weak is high.

Though parity was used as a qualifying criterion during selection, not all cows inseminated conceived. Cows that never conceive following the service may be pointing to some degree of infertility and subfertility in the herd (3). Reproductive diseases are amongst the many factors affecting conception, pregnancy rate and calving rate $(45,51)$. Again, the calving rate recorded in this study could have been higher had it not been due to the drought that South Africa experienced between 2015 and 2016. According to Munyai (10), drought in 1 year results in lower calving the following year. Therefore, drought conditions may have been the cause of pregnancy losses and a lower calving rate.

The body weight and body condition score affects the reproductive performance of the animal and are directly associated with the nutritional status of an animal $(46,51$, 52). Calving rate increases with an improved body condition score $(27,36,44)$. However, in the current study, cows with a body condition score of $\leq 2.5$ had a significantly higher calving rate than those with a body condition score of 3 and $\geq 3.5$. These results might have been influenced by human error on condition score judgement during data collection. Three different enumerators, though trained on body condition scoring $(1-5,1$ $=$ thin, $5=$ obese), worked independently in different provinces. However, Bó and Baruselli et al. (34) reported that cows must have a BCS higher than 2.5 and ideally 3 to achieve a pregnancy rate of $50 \%$ or more. However, the same authors indicated that equine chorionic gonadotropin (eCG) administration during synchronisation allows for a pregnancy rate of close to $50 \%$ in cows with a BCS of $\leq 2.5$. In the current study, an ovsynch protocol that uses progesterone and EB was used instead of eCG.

\section{Perception Analysis Study \\ Human Interference}

Crime statistics reports and surveys in South Africa indicate that rural livestock farmers are affected mainly by stock theft (53). Hangara (54) and Malekano (55) reported about stock theft as a challenge facing communal cattle farmers in Namibia and Malawi, respectively. Stock theft was not as rife during apartheid years in South Africa as it is now. Poverty and unemployment are postulated as the prime cause of theft in these historical settings. Nengovhela (16) reported that most farmers feel that there was better maintenance of the rule of law during apartheid than it is now. Geldenhuys (56) explains that stock theft is an everincreasing, unsettling and destructive reality affecting all sectors of the farming community.

According to the South African Police Service (57), stock theft takes place more often than other forms of criminality, and it is a much more serious threat in South African regions bordering other countries, such as the Eastern Cape, Mpumalanga, Free State, KwaZulu-Natal, North West, and Limpopo. Ever since the fall of apartheid, there has been a rapid expansion of villages and dwellings. Many small, medium, and large enterprises, and tourist attraction businesses such as overnight accommodation and holiday resorts have also been rising. These mushrooming businesses are all at the expense of land originally allocated for grazing and field crops. Nengovhela (16) also reported the expansion of the dwellings at the expense of available grazing as a challenge facing cattle farmers in the low-income sector.

\section{Lack of Resources}

Most low-income beef cattle farmers are located in remote rural areas; and lack the capital to fund the development of infrastructure and construction of handling facilities (58). According to Nkosi and Kirsten (59), inadequate infrastructure merely takes away the limited incentives available to rural farmers. Gwala (12) reported that the poor state of access roads and lack of transport facilities in rural Eastern Cape Province. Almost all the cattle infrastructure currently in existence there was built by the Department of Agriculture $(6,12)$. According to Frisch (58), in communities with facilities, are either in a poor state or non-functional because they were erected some 50-60 years ago, and farmers do not have the cash to maintain them. The lack of infrastructure can seriously 
hinder development initiatives such as the implementation of reproductive technologies in rural farming communities. Ruijs et al. (60) argued that investment in infrastructure has an important positive effect on development. Most of the handling facilities in the hands of communal cattle farmers in Limpopo, Mpumalanga, and KwaZulu-Natal provinces were dilapidated since repairs rarely happen.

According to Bekure and Tilahun (61), marketing provides the mechanism whereby producers transact their livestock for notes. Approximately $40 \%$ of livestock in South Africa is in the hands of low-income farmers (62). The transition from communal and emerging sectors towards commercial production is dependent on market access $(63,64)$. Bailey et al. (65), Montshwe (66) and Musenwa et al. (67) identified poor market infrastructure, increasing market price variability, high transaction costs, and low purchasing power of buyers as major problems resulting in limited market participation. Ainslie et al. (7) identified cultural values and poor production practises rather than market failures as significant causes of limited market participation.

\section{Natural Causes}

According to Mathieu and Yves (68), drought and dry seasons are regular and recurrent features of the South African climate. Their impact on society depends on their intensity and durations. Though this challenge is recurrent, low-income beef cattle farmers had no strategy to deal with the challenge. The results of drought are severe water and feed shortages, and the death of animals. These, in turn, will affect the body condition score and the ability of animals to cycle and conceive, negatively impacting the implementation of reproductive technologies. South Africa experienced severe drought in 2015 through to 2016, and a large number of cattle died during this period. Motiang and Webb (69) found that farmers do not dispose-of their animals even when there is an anticipation of drought. In South Africa, feed availability follows the rainfall patterns with more grazing in summer than in winter. The winter season (May to July) is dry with no rainfall and is characterised by dry grasses of low quality.

Parasites and diseases are among the major constraints faced by communal and emerging beef cattle farmers in developing countries due to several reasons including the unavailability and high cost of drugs and medicines (70). The most problematic diseases listed by respondents were tick-borne diseases such as heart water and redwater, lumpy skin disease, FMD, and abscesses. This scenario is comparable with many authors (7173) who reported tick-borne diseases as the leading cause of substantial losses in cattle production, reduced productivity, the decline in fertility, and often death. However, cattle farmers were aware that indigenous cattle breeds such as the Ngunis are tick and disease resistant, and that they should be promoted since they will fit the low-input low-output production system common in rural setups.

\section{Conclusion}

The results of this study have demonstrated that village cows, irrespective of the province, breed type, parity level, age, body condition score, frame size, lactation status, and geographic location can be successfully synchronised and artificially inseminated with frozen-thawed semen and conceive. Calving rates recorded during the current study were higher than those recorded under natural mating. There was an increase in conception rate with an increase in body condition score. So, good nutrition is essential for an improved conception rate. Cows that were lactating during the implementation of the assisted reproductive technologies project had more chances to calve than those that were not lactating, thus affirming that calving is a good measure of the reproductive efficiency in a herd. Large framed animals had a higher conception rate than small and medium-framed animals. However, their feed maintenance requirement will compromise their performance in lower rainfall areas such as the Limpopo Province. It is advisable for farmers in lower rainfall areas to farm with small to medium framed animals such as the Ngunis with lower feed maintenance requirements. There are many of challenges that can reduce the accessibility of reproductive technologies under the lowincome beef sector in South Africa. Low-income beef cattle farmers need to identify challenges within their reach instead of waiting for the government. The government is stretched with ever-rising social challenges and depleting resources. All stakeholders that participated in the project agreed that the observed results were encouraging and serves as an inspiration for the adoption of the practise. Other provinces in the country that were not participating in the study closely monitored the practical outcome of the project. It did not come as a surprise that KwaZulu-Natal that participated in the study, and North West Province that did not participate in the project, adopted ART practises to support reproductive performance in the low-income beef sector.

\section{DATA AVAILABILITY STATEMENT}

The raw data supporting the conclusions of this article will be made available by the authors, without undue reservation.

\section{ETHICS STATEMENT}

The animal study was reviewed and approved by University of Fort Hare Animal Research Ethics (NED011SMUG01). Written informed consent was obtained from the owners for the participation of their animals in this study.

\section{AUTHOR CONTRIBUTIONS}

$\mathrm{TM}, \mathrm{TN}$, and $\mathrm{KN}$ : conceptualisation, methodology, and validation. TN: funding acquisition. TM and TN: organisation and data collection. TM and $\mathrm{KN}$ : data screening and analysis. $\mathrm{TM}$ and $\mathrm{NN}$ : administration and writing. TN and $\mathrm{KN}$ : reviewing and editing. All authors had read and agreed to the published version of the manuscript.

\section{FUNDING}

The project was funded by the Technology Innovation Agency (TIA) of the Department of Science and Technology (DST). 


\section{ACKNOWLEDGMENTS}

The authors would like to acknowledge the Germplasm, Conservation and Reproductive Biotechnologies (GCRB) unit of the Agricultural Research Council and, in particular, Mr. Mphaphathi and Dr. Ramukhithi, the University of Fort Hare for study opportunity and the University of Limpopo for

\section{REFERENCES}

1. Department of Agriculture, Forestry and Fisheries. A Profile of the South African Beef Value Chain. Marketing Directorate, Private Bag x 15, Arcadia, 0007, South Africa (2018).

2. Statistics South Africa. Community Survey, Agricultural Households. Report No. 03-01-05, ISBN978-0-621-44949-5, Published by Statistics South Africa (2016).

3. Mokantla E, McCrindle CME, Sibei JP, Owen R. An investigation into the cause of low calving percentage in communally grazed cattle in Jericho, North West Province. JS Afri Vet Assoc. (2004) 75:30-6. doi: 10.4102/jsava.v75i1.445

4. Gaudex L. A Health and Demographic Surveillance System of Cattle on Communal Rangelands in Bushbuckridge, South Africa: Baseline Census and Population Dynamics Over 12 Months. Pretoria: MSc Animal Health, University of Pretoria (2014).

5. Mugwabana TJ. The role of assisted reproductive technologies in improving cattle production under communal and emerging farming systems in South Africa. (PhD thesis). Department of Livestock and Pasture Science, University of Forth Hare, Alice, South Africa (2018).

6. Tada O, Muchenje V, Dzama K. Reproductive efficiency and herd demography of Nguni cattle in village-owned and group owned enterprises under lowinput communal production systems. Trop Anim Health Prod. (2013) 45:1321-9. doi: 10.1007/s11250-013-0363-x

7. Ainslie A, Kepe T, Ntsebeza L, Ntshona Z. Turner S. Cattle Ownership and Production in the Communal Areas of the Eastern Cape, South Africa. Research Report No.10. University of the Western Cape, Cape Town, South Africa (2002).

8. Stroebel A, Swanepoel FJC, Pell AN. Sustainable smallholder livestock systems: a case study of Limpopo Province, South Africa. Livest Sci. (2011) 139:825-8. doi: 10.1016/j.livsci.2011.03.004

9. Schwalbach LM, Groenewald IB, Marfo CB. A survey of small-scale cattle farming systems in the North West Province of South Africa. Anim Sci J. (2001) 31:200-2004. doi: 10.4314/sajas.v31i3.3794

10. Munyai FR. An evaluation of socio-economic and biophysical aspects of smallscale livestock systems based on a case study from Limpopo Province: Muduluni village (PhD thesis). Department of Animal, Wildlife and grassland Science, University of Free State, Bloemfontein, South Africa (2012).

11. Bester J, Matjuda LE, Rust JM, Fourie HJ. The Nguni: A Case Study. Animal Improvement Institute, Irene (2003). p. 1-36.

12. Gwala L. Effect of agricultural extension services on beneficiaries of the nguni cattle project: the case of Ncera and Kwezana villages, Eastern Cape Province (MAgric dissertation). Department of Agricultural Economics and Extension, Faculty of Science and Agriculture, University of Fort Hare, Alice, South Africa (2013).

13. Ndove TS, Whitbread AM, Clark RA, Pengelly BC. Identifying the factors that contribute to the successful adoption of improved farming practices in the smallholder sector of Limpopo Province, South Africa. In: Whitbread AM, Pengelly BC, editors. Tropical Legumes for Sustainable Farming Systems in Southern Africa and Australia. ACIAR Proceedings (2006). p. 115.

14. Muzari W, Gatsi W, Muvhunzi S. The impact of technology adoption on smallholder agricultural productivity in Sub-Saharan Africa: a review. J Sustain Dev. (2012) 5:69-77. doi: 10.5539/jsd.v5n8p69

15. Census. Census Report by the Statistics South Africa. Pretoria (2011).

16. Nengovhela NB. Improving the wellbeing of people dependent on the lowincome beef industry in South Africa ( $\mathrm{PhD}$ thesis). School of Integrative Systems, University of Queensland, QLD, Australia (2011). providing funding for the Ph.D. study. They also want to acknowledge the support provided by Provincial Departments of Agriculture in Limpopo, Mpumalanga, and KwaZuluNatal. The Technology Innovation Agency (TIA) for financial support of the research. The content of this manuscript has been published (in part) as part of the thesis of Mugwabana (5).

17. Oni SA, Nesamvuni AE, Odhiambo JJO, Dagada MC. Study of Agricultural Industry in the Limpopo Province (Executive Summary). (2012). p. 1-57.

18. Molefi SH, Mbajiorgu CA, Antwi MA. Management practices and constraints of beef cattle production in communal areas of Mpumalanga Province, South Africa. Indian J Anim Sci. (2017) 51:187-92. doi: 10.18805/ijar.11325

19. Fairbanks DHK, Benn GA. Identifying regional landscapes for conservation planning: a case study from KZN, South Africa. Landsc Urban Plan. (2000) 50:237-57. doi: 10.1016/S0169-2046(00)00068-2

20. Olander S, Landin A. Evaluation of stakeholder influence in the implementation of construction projects. Int J Proj Manag. (2005) 23:321-8. doi: 10.1016/j.ijproman.2005.02.002

21. Nicholson MJ, Butterworth MH. A Guide to Condition Scoring in Zebu Cattle. Addis Ababa: ILRI (aka ILCA and ILRAD) (1986).

22. Statistical Analysis System. SAS Guide for Personal Computers. Cary, NC:Statistical Analysis System (2003).

23. Straus AL, Corbin J. Basics of qualitative research. Techniques and Procedures for Developing Grounded Theory. 4th ed. London: SAGE Publication (2014).

24. Martinez MF, Kastelic JP, Adams GP, Janzen E, McCartney DH, Mapletoft RJ. Estrus synchronization and pregnancy rate in beef cattle given CIDR-B, prostaglandin and estradiol or GnRH. Can Vet J. (2000) 41:786-90.

25. Maqhashu A. Application of assisted reproductive technologies on the indigenous Nguni cows and heifers (MSc dissertation). Department of livestock and pasture Science, University of Fort Hare, Alice, South Africa (2013).

26. Rahman MS, Khan MKI, Bilkis T. Effect of flushed feeding and age on estrus synchronization and conception rate of Holstein $\mathrm{x}$ local crossbred cows after using analogue GnRH and prostaglandin F2 $\alpha$ hormone. Iran J Appl Anim Sci. (2014) 4:493-7.

27. Raphalalani ZC. Introduction of Genetic Materials Through Assisted Reproductive Technologies in Communal Cows of Limpopo Province. A mini-dissertation. Pretoria: MTECH (Agriculture), Tshwane University of Technology (2016).

28. Cabara IV, Velicevici S. Ovysnch protocol versus cosynch in dairy cows. Sci Papers Anim Sci Biotechnol. (2013) 46:63-5.

29. Bó GA, Baruselli PS, Martinez MF. Patterns and manipulation of follicular development in Bo indus cattle. Anim Reprod Sci. (2003) 78:307-26. doi: 10.1016/S0378-4320(03)00097-6

30. Alvarez P, Spicer LJ, Chase CC, Jr., Payton ME, Hamilton TD, Steward RE, et al. Ovarian and endocrine characteristics during the oestrous cycle in Angus, Brahman and Senepol cows in subtropical environment. Anim Sci J. (2000) 78:1291-302. doi: 10.2527/2000.7851291x

31. Alnimer M, De Rosa G, Grasso F, Napolitano F, Bordi A. Effect of climate on the response to three synchronisation techniques in lactating dairy cow. Anim Reprod Sci. (2002) 71:157-68. doi: 10.1016/S0378-4320(02)00021-0

32. Hansen PJ. Impact of Heat Stress on Female Fertility. Available online at: http://www.animal.ifas.ufl.edu/beef_extension/bcsc/2015/speaker_ proceedings/hansen.pdf (accessed June 21, 2020).

33. Smith MF, Pohler KG, Perry GA, Patterson D. Physiological factors that affect pregnancy rate to artificial insemination in beef cattle. In: Proceedings Applied Reproduction Strategies in Beef Cattle, December, 3-4, Dakota, USA. (2012). p. 33-51.

34. Baruselli PS, Reis EL, Marques MO, Nasser LF, Bó GA. The use of hormonal treatments to improve reproductive performance of anestrous beef cattle in tropical climates. Anim Reprod Sci. (2004) 82-83:479-86. doi: 10.1016/j.anireprosci.2004.04.025 
35. Borges LFK, Ferreira R, Siqueira LC, Bohrer RC, Borstmann JW, De Oliveira JFC, et al. Artificial insemination system without estrous observation in suckled beef cows. Cienc Rural. (2008) 39:2. doi: 10.1590/S0103-84782008005000075

36. Woldu T, Giorgis YT, Haile A. Factors affecting conception rate in artificially inseminated cattle under farmers' condition in Ethiopia. J Cell Anim Biol. (2011) 5:334-8. doi: 10.5897/JCAB11.067

37. Desalegn G. Assessment of problems/constraints associated with artificial insemination service in Ethiopia (MSc thesis). Addis Ababa University, Faculty of Veterinary Medicine, Debre Zeit, Addis Ababa, Ethiopia (2008).

38. Ali T, Lemma A, Yilma $\mathrm{T}$. Reproductive performance of dairy cows under artificial insemination in south and northwest part of Ethiopia. Livest Res Rural Dev. (2013) 25:191. http://www.lrrd.org/lrrd25/11/ali25191. htm

39. Garcia M, Huanca W, Echevarria L. Reproductive performance of peurebred and crossbred zebu cattle under artificial insemination in the Amazon tropics. Animal Sci. (1990) 50:41-49.

40. Mukasa-Mugerwa E, Tegegne A, Ketema H. Patterns of postpartum oestrus onset and associated plasma progesterone profiles in Bos indicus cows in Ethiopia. Anim Reprod Sci. (1991) 24:73-84. doi: 10.1016/0378-4320(91)90083-C

41. Bó GA, Baruselli PS. Synchronisation of ovulation and fixed-time artificial insemination in beef cattle. Animal. (2014) 8:144-50. doi: $10.1017 /$ S1751731114000822

42. Mabry KL. Comparison of synchronisation protocols in beef cattle (MSc thesis). North Carolina State University, USA (2013).

43. Chebel RC, Santos, JEP, Reynolds, JP, Cerri RLA, Juchem SO, Overton M. Factors affecting conception rate after artificial insemination and pregnancy rate loss in lactating dairy cows. Anim Reprod Sci. (2004) 84:239-55. doi: 10.1016/j.anireprosci.2003.12.012

44. Bó GA, Cutaia L, Peres LC, Pincinato D, Maraña D, Baruselli PS. Technologies for fixed-time artificial insemination and their influence on reproductive performance of Bos indicus cattle. In: Juengel JL, Murray JF, Smith MF. Reproduction in Domestic Ruminants VI. Nottingham: Nottingham University Press (2007). p. 223-36.

45. Nqeno N, Chomonyo M, Mapiye C, Marufu MC. Ovarian activity, conception and pregnancy patterns of cows in the semiarid communal rangelands in the Eastern Cape Province of South Africa. Anim Reprod Sci. (2010) 118:140-7. doi: 10.1016/j.anireprosci.2009.07.006

46. Montiel F, Ahuja C. Body condition and suckling as factors influencing the duration of postpartum anestrus in cattle: a review. Anim Reprod Sci. (2005) 85:1-26. doi: 10.1016/j.anireprosci.2003.11.001

47. Mapiye C, Chimonyo M, Dzama K, Marufu MC. Protein status of indigenous Nguni and crossbred cattle in the semi-arid communal rangelands of South Africa. J Anim Sci. (2010) 23:213-5. doi: 10.5713/ajas.2010. 90200

48. Scholtz MM. South Africa's Beef Industry. Pretoria: Irene (2005).

49. Pursley JR, Silcox RW, Wiltbank MC. Effect of time of artificial insemination on pregnancy rates, calving rates, pregnancy loss and gender ratio after synchronisation of ovulation in lactating dairy cows. J Dairy Sci. (1998) 81:2139-44. doi: 10.3168/jds.S0022-0302(98)75790-X

50. King BH. Conservation and community in the new South Africa: a case study of the Mahushe Shongwe Game Reserve. Sci Direct Geoforum. (2007) 38:207-19. doi: 10.1016/j.geoforum.2006.08.001

51. Chimonyo M, Kusina NT, Hamudikuwanda HA, Nyoni O, Ncube I. Effect of dietary supplementation and work stress on ovarian activity in non-lactating Mashona cows in a smallholder farming area of Zimbabwe. Anim Sci. (2000) 70:317-23. doi: 10.1017/S1357729800054771

52. Chimonyo M, Kusina NT, Hamudikuwanda HA, Nyoni O. Reproductive performance and body weight changes in draught cows in a smallholder semiarid farming area of Zimbabwe. Trop Anim Health Prod. (2000) 32:405-15. doi: 10.1023/A:1005285720169

53. Maluleke W, Mokwena RJ, Motsepa LL. Rural farmers' perspectives on stock theft: police crime statistics. S Afri J Agric Ext. (2016) 44: 256-274. doi: 10.17159/2413-3221/2016/v44n2a393
54. Hangara GN. Challenges facing communal farmers to improve cattle production and marketing systems in Namibia: Case study from Omaheke region. ( $\mathrm{PhD}$ thesis). Centre of Sustainable Agriculture, Faculty of Natural Science and Agricultural Sciences, University of Free State, Bloemfontein, South Africa (2011).

55. Malekano L. The socio-economic impact of stock-theft and disease in the lower Shire district of Malawi. In: A Paper Presented at the International Conference on Historical and Social Sciences Research in Malawi. (2000). p. 26-9.

56. Geldenhuys K. Stock theft evidence. Servamus Commun Based Saf Secur Mag. (2006) 34:37-8

57. South African Police Service. Remarks by the Minister of Police, EN. Mthethwa, MP, on the Occasion of the Release of the 2011/12 SAPS National Crime Statistics, Parliament, Cape Town - 20 September 2012 - Full text of crime statistics speech, Independent Online. Available online at: https://www.gov.za/remarks-minister-police-en-mthethwa-mpoccasion-release-201112-saps-national-crime-statistics (accessed September 17, 2018).

58. Frisch JE. Towards a permanent solution for controlling cattle ticks. Int J Parasitol. (1999) 29:57-71. doi: 10.1016/S0020-7519(98)0 0177-5

59. Nkosi SA, Kirsten JF. The marketing of livestock in South Africa's developing areas: a case study of the role of speculators, auctioneers, butchers and private buyers in Lebowa. Agrekon. (1993) 2:200-37. doi: 10.1080/03031853.1993.9524747

60. Ruijs AJW, Schweigman C, Lutz C. The impact of transport and transaction cost reduction on food market in developing countries: evidence of tempered expectations for Bukina Faso. Agric Eco. (2004) 31:219-28. doi: 10.1016/j.agecon.2004.09.009

61. Bekure S, Tilahun N. Livestock marketing studies. In: Pastoral Systems Research in Sub-Saharan Africa. Proceedings of the IDRC/ILCA workshop held at ILCA, Addis Ababa, Ethiopia, 21-24 March. (1983). p. 327-360.

62. Department of Agriculture, Forestry and Fisheries. Statistics and Economic Publication and Reports. Livestock Numbers from 1996 to Current. (2017). Available online at: www.daff.gov.za/daff web3/Home/Crop-Estimates/Statistical-Information/Livestock (accessed June 14, 2017).

63. Jooste A, Van Rooyen CJ. Access to emerging farmer in the red meat industry. In: All Africa Conference on Animal Agriculture, Pretoria, South Africa (1996).

64. Jooste A. Economic implications of trade liberalisation on the South African red meat industry ( $\mathrm{PhD}$ thesis), University of the Free State, Bloemfontein, South Africa (2001).

65. Bailey D, Barrett CB, Little PD, Chabari F. Livestock Markets and Risk Management Among East African Pastoralists: A Review and Research Agenda. Research report, Utah: Utah University (1999).

66. Montshwe BD. Factors affecting participation in mainstream cattle markets by small-scale cattle farmers in South Africa. MSc Mini-Dissertation, department of Agricultural Economics, University of Free State, Bloemfontein, South Africa (2006).

67. Musemwa L, Chagwiza C, Sikuka W, Fraser G, Chimonyo M, Mzileni N. Analysis of cattle marketing channels used by small-holder farmers in the Eastern Cape Province, South Africa. Livest Res Rural Dev. (2007) 19:131. http://www.lrrd.org/lrrd19/9/muse19131.htm

68. Mathieu R, Yves R. Intensity and spatial extension of drought in South Africa at different times scales. Water SA. (2003) 29:489-500. doi: 10.4314/wsa.v29i4.5057

69. Motiang DM, Webb EC. Herd mortality and cattle off-take rates among smallholder producers in the North West Province of South Africa. Afr J Agric Res. (2016) 11:930-4. doi: 10.5897/AJAR201 4.9424

70. Ndebele JJ, Muchenje V, Mapiye C, Chimonyo M, Musemwa L, Ndlovu T. Cattle breeding management practices in the Gwayi smallholder farming area of South- Western Zimbabwe. Livest Res Rural Dev. (2007) 19:1-9. http:// www.lrrd.org/lrrd19/12/ndeb19183.htm 
71. Mapiye C, Chimonyo M, Dzama K, Raats JG, Mapekula M. Opportunities for improving Nguni cattle production in the smallholder farming systems of South Africa. Livest Sci. (2009) 124:196-204. doi: 10.1016/j.livsci.2009. 01.013

72. Rajput ZI, Hu SH, Chen WJ, Arijo AG, Xiao CW. Importance of ticks and their chemical and immunological control in livestock. J Zhejiang Univ Sci. (2006) B7:912-21. doi: 10.1631/jzus.2006.B0912

73. Swai ES, Karimuribo ED, Kambarage DM. Risk factors for smallholder dairy cattle mortality in Tanzania. JS Afr Vet Assoc. (2010) 81:241-6. doi: $10.4102 /$ jsava.v81i4.155

Conflict of Interest: The authors declare that the research was conducted in the absence of any commercial or financial relationships that could be construed as a potential conflict of interest.
Publisher's Note: All claims expressed in this article are solely those of the authors and do not necessarily represent those of their affiliated organizations, or those of the publisher, the editors and the reviewers. Any product that may be evaluated in this article, or claim that may be made by its manufacturer, is not guaranteed or endorsed by the publisher.

Copyright (c) 2021 Nengovhela, Mugwabana, Nephawe and Nedambale. This is an open-access article distributed under the terms of the Creative Commons Attribution License (CC BY). The use, distribution or reproduction in other forums is permitted, provided the original author(s) and the copyright owner(s) are credited and that the original publication in this journal is cited, in accordance with accepted academic practice. No use, distribution or reproduction is permitted which does not comply with these terms. 